

\section{The Influence of Dividend Payments on Share Price in Manufacturing Firms Quoted on the Nigerian Stock Exchange}

\section{Samson Ogege}

\section{Introduction}

The basic concept of dividend payout as well as its policy has remained one of the major issues generating controversy in corporate finance. Since the inception of joint stock firms, the payment of dividend by firms has become an interesting issue in financial literature. Over the years, the modeling as well as the evaluation of corporate dividend payout and returns had been engaged by financial economists as they influence the stock price of firms in Nigeria (AlQudah et al., 2015). In a simple form, dividend is the apportionment of returns or earnings in real assets amidst the company's shareholders in relation to their share ownership. The payment of dividend is quite sacrosanct for the effective and efficient management of a business operation to ensure its survival and it has been viewed as one of the most vital tools for assessing the existence and performance of corporate organizations. A great value is performed by dividends to restore confidence to the shareholders and it is extremely significant as a result of its negative influence on the values of share. A stable policy on dividend is anticipated to bring about a higher price of share due to the high level investors' confidence regarding the potential of the firm to make higher profit in the future. However, the firm still needs to be assessed in a wider scope. Basically, at the end of every financial period, firms assess their financial performance by determining whether earnings had been actualized or not.

The payment of dividend continues to be viewed as one of the major significant financial policies not just only from the firms' outlook, but as well from that of the employees, the consumers, shareholders, regulatory bodies as well as the government (Jakata and Nyamugure, 2015). It is generally specified as a nominal value percentage of the ordinary share capital of firm or as a stable amount per share. In all, when the market is greatly influenced either positively or negatively, it may as well pose a similar influenced on the payment and policies of dividend. AlQudah et al. (2015) posited that, the rationale behind the dividend payout of firms is the need for cash and/or to avoid the cost of agency and minimizing the insecurity of investors. Sharma (2011) indicated that, earnings and dividend per share are key components that provide vital information regarding the share price's value in the market.

Previous studies conducted in Nigeria on dividend payout appeared to have revealed that, the dividend payment trend had been inconsistent in various sectors of the economy. Jakata and Nyamugure (2015) came up with the conclusion that, the association of dividend payment with equity on shares prices has produced conflicting results based on the sector the study is conducted. However, considering the manufacturing industry, the payment of dividend has been inconsistent. Thus, the challenges identified prompted the researcher to carry out this study with the main purpose of ascertaining the influence of dividend payment on share prices of the quoted manufacturing firms.

\section{Literature Review}

Based on this theory, Lintner (1956) and Gordon (1959) formally contended that, there is need for the investors to actualize their wealth for the purpose of consumption and hence prefer cash dividends to capital gains. However, it was theoretically opposed by Miller and Modigliani (1961) in their seminar paper revealing that dividends and capital gains are substituted for each other. Again, 'home-made dividends' could be produced by the investors by issuing stock if that is what they have decided to do. This theory is majorly adopted by firms for justifying the essence of having a well-established dividend policy in operation. Traditionally, the Bird in Hand Theory posits that, the share prices of firms can be influenced via variation in their policies of dividend. The theory further asserts that, dividend is preferred by the investors to capital gain for that 'A bird in the hand is worth more than one in the bush'. That is to say, dividend today is more preferred than capital gain that is not certain in the future (Gordon, 1963).

Several empirical studies had been conducted home and abroad on the association of dividend payment and policy with share price as to whether there exists a positive or negative association between the variables. Few of such studies are empirically reviewed below:

A study was conducted in Nigeria by Augustine et al. (2019) investigating the association of the ratio of dividend payout with the value of brewery and beverage companies quoted on the Nigerian Stock Exchange (NSE). The study also examined other factors that influence the value of firm. However, the variables (cash holding, profitability, size of company as well as leverage and dividend policy ratio) were regarded as the factors influencing the value of companies. OLS regression analysis was adopted to analyze the secondary data collected from the firms spanning from 2007-2016. It was established that, profitability and leverage ratio have significant and positive influence on the companies' value. This implies that, only the variables of Firm Leverage, and Profit after Tax are significant factors that drive firm value in both breweries and beverages companies among listed companies in Nigeria. Hence, the work suggested that, policies which will optimize the leverage ratio of companies should be put in place and that companies which wish to optimize their values should ensure that profit after tax is maximized.

Adopting a panel least square regressions method, Alfred et al. (2019) appraised the dividend policy influence on the prices of stock of ten consumer goods companies listed on the Nigerian stock exchange. The secondary data adopted were collected from the financial statements of the firms investigated spanning 
from 2011 to 2015 and established that dividend yield influences market price share insignificantly and adversely; earnings per share and dividend pay-out ratio influenced market price share significantly and positively while net asset per share show non-significant positive impact on market price share. In view of the outcomes of the analysis, it was inferred that the policy of dividend has the potential to impact on the prices of stock in the consumer goods sector pointing out that the irrelevancy theory of dividends does not take effect as the case may be in Nigeria.

By investigating about two hundred and twenty-eight quoted companies in the Amman Stock Exchange, Muhannad et al. (2018) obtained the data spanning from 2010 to 2016 to ascertain the influence of dividend policy on the fluctuation of stock price of the study sample. With the adoption of Pearson correlation analysis and the estimation of panel GMM to investigate the association between the observed variables, it was established that dividend policy and payout, dividend yield have adverse significant causality with stock price fluctuation. It therefore means that the more the companies increase their dividend payout and dividend yield, there will be more reduction in the fluctuation of the price of stock which invariably brings about a more stable stock price. Hence, the study recommended that dividend policy that is favorable to both the current and future investors should be formulated and maintained by the companies quoted on the Amman Stock Exchange.

Between 2006 and 2015, a similar study was conducted in Nairobi for a case of six insurance firms quoted on the Nairobi Securities Exchange and it was revealed based on the regression analysis adopted by Joseph and Symon (2017) that earnings per share, dividend yield and inflation significantly and positively influenced the share price value. Based on the outcomes established, it is inferred that dividend policies should be thoroughly and accurately considered by the insurance companies as a result of their potentials to impact the price of share by making the price of stock to either increase or decrease based on the dividends declared by the firms' management. Thus, it is highly required by the management to be honest and responsive in dividends declaration.

To further ascertain how the payment of dividend affects the share value, Akram (2017) sourced for data from 44 companies quoted on Istanbul Stock Exchange spanning from 2007-2015 and a fixed effect analysis was employed. The result from the analysis indicated that, the payment of dividend has a significant and positive association with companies' value. Thus, the outcomes of this study upheld the agency cost theory inferred that, the irrelevance hypothesis of dividends is not valid considering the companies quoted on the ISE.

Ahmed et al. (2017) conducted a study on the association of dividend policy with the stock prices belonging to a firm in the banking sector. The data between 2005 and 2014 regarding the financial structure as well as the basic dividend policies of the firms investigated were sourced from the financial statement of five banks selected and the websites of State Bank of Pakistan and Karachi Stock Exchange. The outcomes indicated that, a sound dividend policy plays a significant function in alluring potential investors as well as making a substantial contribution towards enhancing the financial structure of companies. Furthermore, it was revealed by the findings that dividend policies might pose a significant and positive effect on the prices of stock if considered and executed after thorough investigation of financial structure as well as the dividend policies of various companies.

\section{Methodology}

Secondary data were employed in this study and had been collected from the financial statement and average share prices per year of the chosen manufacturing companies quoted on the Nigerian stock exchange spanning from 2004-2018. The study covers manufacturing companies that specialize in consumer goods, industrial goods, technological development, oil and gas, health care and basic materials. Panel Ordinary Least Square Technique was adopted for analyzing the panel data in order to assess the influence and the association between the variables observed in this research.

On the basis of this literature, the model was formulated as follows:

$\mathrm{SP}=\mathrm{f}(\mathrm{DPS}, \mathrm{EPS}, \mathrm{DY}$

$\mathrm{CR})$ Eq. 1 $S P_{t}=\boldsymbol{\beta}_{0}+\boldsymbol{\beta}_{1} D P S_{t}+\boldsymbol{\beta}_{2} E P S_{t}+\boldsymbol{\beta}_{3} D Y_{t}+\boldsymbol{\beta}_{4} C R_{t}$
$+\mu_{t} \ldots \ldots \ldots \ldots \ldots \ldots \ldots \ldots \ldots$ Eq. 2

Where: SP -Share Price; DPS - Dividend Per Share; EPS - Earnings Per Share; DY - Dividend Yield; CR - Credit Risk ; $\mathrm{B}_{0}=$ Slope of the regression; $\mathrm{B}_{1,2,3}$ Coefficient of the variables

$\mathrm{U}=$ Error term

Model Specification in Linear Form

\section{Data Analysis}

Regression Analysis for High Geared Manufacturing Firms

Investigate the influence of dividend per share on the price of share of high geared manufacturing firms in Nigeria.

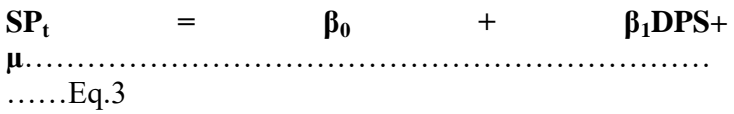


Table 1: Regression Result of High Geared Manufacturing Firms

Dependert Variabie sp Pest Leat Squres Methed

Dine: 09:2019 Time

7 croste. 20142013

Oeservatiens iteludat 35

\begin{tabular}{|c|c|c|c|c|}
\hline Varialte & Coefricient & Sta Erar & 1. Stusitic & Pinth. \\
\hline $\mathrm{DPE}$ & 1631185 & 0.103825 & 14.98010 & 0,0080 \\
\hline
\end{tabular}

Crost-eection faed (tummy variatics)

\begin{tabular}{|c|c|c|c|}
\hline R-yaned & $0.5394+16$ & Alen dependent vay & 2053000 \\
\hline Adruiled $\mathrm{R}$-unarent & 0.530151 & 5D dnoodint yat & 0.614203 \\
\hline SE of reorition & 0.616106 & Abaikr infe crilerien & 1970915 \\
\hline Sum squesed resid & $84.6477 n$ & Schewr exiterion & 2351233 \\
\hline Lee Ektititoos & -210.3644 & Hinas-Quian ainer & 2123052 \\
\hline F-axtios: & 0.94732 & Dirtid-Wuaten wa & 3575142 \\
\hline Prodif-statistic? & 0.542169 & & \\
\hline
\end{tabular}

Source: Eview7, 2019

Analysis for Low Geared Manufacturing Firms

Restatement of Objective One

Assess the influence of dividend per share on the price of share of quoted low geared manufacturing firms in Nigeria.

$\begin{array}{lllll}\mathbf{S P}_{\mathbf{t}} & = & \boldsymbol{\beta}_{0} & + & \boldsymbol{\beta}_{1} \mathrm{DPS}+\end{array}$

Table 2: Regression Outcome

\begin{tabular}{|c|c|c|c|c|}
\hline 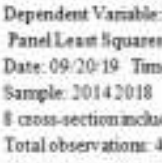 & & & & \\
\hline Vatiable & Couffointe & Std Entet & 4-5tatintie & Frob \\
\hline c & 6285310 & 0.534851 & $99002 n$ & 0.0000 \\
\hline DPS & 0.021694 & 0068135 & 0.318404 & 0.0005 \\
\hline Crowesection fixed & iatler) & & & \\
\hline R-squared & 0.439446 & Metan dependentvar & & 2033000 \\
\hline Adfuted K-.quared & $0.49015 t$ & S.D. dependent var & & 0.613403 \\
\hline SE ofregression & 0.616106 & Akaike info critensa & & 1970913 \\
\hline Som squaredreaid & 84.64777 & Schoun caterion & & 2351233 \\
\hline Log thetihood & -2193644 & Hannm-Qunn criter & & $2.12398:$ \\
\hline F-statitic & 0.947132 & Dation-Watson stat & & 2.11111: \\
\hline Prob(F-vatialtie) & 0.542160 & & & \\
\hline
\end{tabular}

Source: Eview7, 2019

Analysis for Dividend Paying Manufacturing Firms

Restatement of Objective Two

Understand the impact of earnings per share on the price of share of quoted dividend paying manufacturing firms in Nigeria.

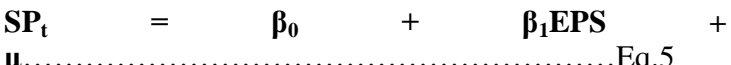

Table 3: Regression Outcome for Dividend Paying Firms

Dependers Variatie: 5

Puel Leas Squares

Die: 092119 Time: 0911

Sxplie 30143018

10 ana-wation itrobind

Devervisam so

\begin{tabular}{|c|c|c|c|c|}
\hline Vmable & Coefficient & Ste. Inoe & V.Stutiatic & Prob. \\
\hline c & a.tat15 & 0.258927 & 2083681 & $0038:$ \\
\hline EPS & 0.730471 & 0.021457 & 34,46236 & 0000 \\
\hline
\end{tabular}

\begin{tabular}{|c|c|c|c|}
\hline R-aparad & 0.974030 & Meas dependete va & 0023363 \\
\hline A-uated $R$-uquet & 0970234 & S.D. dependent ye & 0020852 \\
\hline $5 \mathrm{E}$ at regresicos & 0.06244 & Ahule info criterice & 0.070510 \\
\hline Sam squared resid & 1.46450 & Sctwarr crsteico & $0.05010 t$ \\
\hline Leg likestaood & 134.3957 & Hime-Quim criter. & $1.63455:$ \\
\hline $\mathrm{F}$-ntatiotie: & 256.6171 & Dertin-Wremen the & 103284 \\
\hline Prot $f$-exilito & 0050000 & & \\
\hline
\end{tabular}

Analysis for Non-Dividend Paying Manufacturing Firms

Restatement of Objective Two

Understand the impact of earnings per share on the price of share of listed non-dividend paying manufacturing companies in Nigeria.

$$
\mathrm{SP}_{\mathrm{t}}=\boldsymbol{\beta}_{0}+\boldsymbol{\beta}_{1} \mathrm{EPS}+
$$

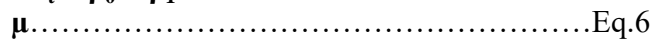

Table 4: Regression Outcome for Non- Dividend Paying Manufacturing Firms

Dependent Viame S

Pawe keat Squares

Dnit: 092819 Tine: 0427

Smpir: 2014 2015

Imvived 10 anew-vectice

Totes obueriatiose 50

\begin{tabular}{|c|c|c|c|c|}
\hline Vanatile & Coefititent & Stu Emar & 8-Statiate & Prot. \\
\hline c & 2132285 & a jomss & 0.4T81:5 & 0.0000 \\
\hline EPS & 0.402581 & 0.025042 & D. 372702 & 0.0000 \\
\hline
\end{tabular}

Croas section fired (dummy variaties)

\begin{tabular}{|c|c|c|c|}
\hline R. - squarest & 0.531201 & Sean oppecteat vut & 2.100000 \\
\hline Aquated tr, squxed & 0.521111 & SD deperseat vx & 0,722403 \\
\hline S. of regreavis & 0.359922 & Nailke isto cruteios & 1070335 \\
\hline Sum gquared rest & 81.64227 & Schrarz citernsn & 1351173 \\
\hline Log itikelitiond & 1193622 & Hamm-Quin criter. & 1. 100062 \\
\hline $\mathrm{F}$-atutiox & 0.312563 & Durbin-Watbon stat & $256001 \mathrm{t}$ \\
\hline Probof-triticic) & 0.256182 & & \\
\hline
\end{tabular}

Analysis for Old Manufacturing Firms

The firms presented in the data presentation were regrouped into old and new manufacturing firms based on their year of operation as manufacturing firms in Nigeria.

Restatement of Objective Three

Find out the influence of dividend yield on the price of share of quoted old manufacturing firms in Nigeria. 
$\mathrm{SP}_{\mathbf{t}}=\boldsymbol{\beta}_{0}+\boldsymbol{\beta}_{1} \mathrm{DY}+$

H........................................... 7

Table 5: Regression Outcome for Old Manufacturing Firms

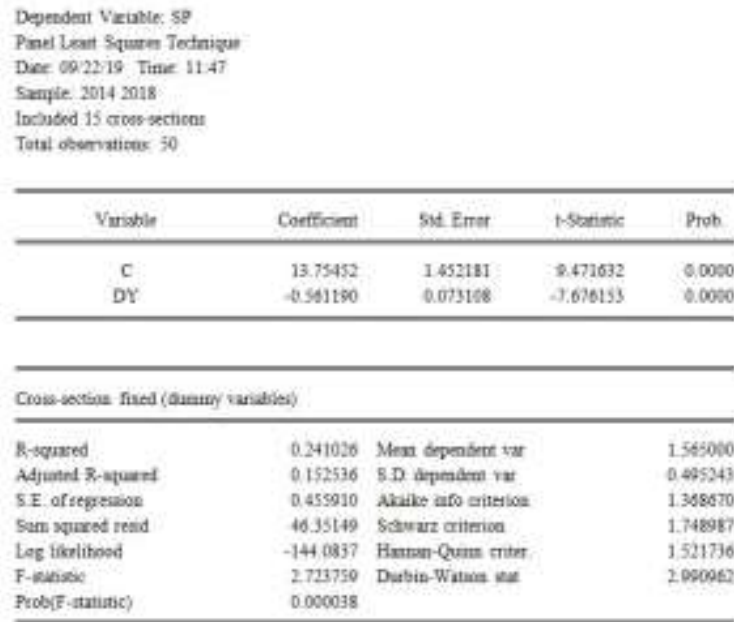

Source: Eview7, 2019

Analysis for New Manufacturing Firms

Restatement of Objective Three

Find out how dividend yield influences the share price of quoted new manufacturing firms in Nigeria.

$$
\mathbf{S P}_{\mathbf{t}}=\boldsymbol{\beta}_{0}+\boldsymbol{\beta}_{1} \mathrm{DY}+
$$

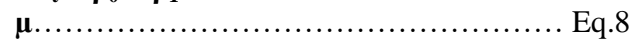

Table 6: Regression Outcome for New Manufacturing Firms

Depedent Vrinte: \&P

Pest Leal Sques Totriege

Don 082219 Time: $11: 5$ ?

Sactele 20142018

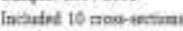

Tutal observanos: 50

\begin{tabular}{|c|c|c|c|c|}
\hline Veialt: & Coethoieat & SuL Enor & t.Sutititie & Prot: \\
\hline c & 3.487619 & 3,745025 & Gsonos & 0.000 \\
\hline DY & $-0.81+236$ & 0.390257 & 2 atses & 0.003 \\
\hline
\end{tabular}

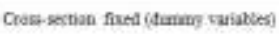

\begin{tabular}{|c|c|c|c|}
\hline R soguxot & $0.063 \pi$ & Mesw dejecterer vy & 3047000 \\
\hline Mjoued R-aquand & 0.174367 & S.D dependat ix & Lo6sts1 \\
\hline 5. of regresing & 1.803852 & Ahaiks infe critenica & 4116914 \\
\hline Sumb uquared reald & 725.5693 & Stancez criterica & 4.459732 \\
\hline Las Pkeitheod & -4879888 & Hatran-Quin critn & $42 m a 1$ \\
\hline
\end{tabular}

Source: Eview7, 2019

Analysis for Big Manufacturing Firms

Restatement of Objective Four

Assess how credit risk influences the share price of quoted big and small manufacturing firms in Nigeria.

$\mathrm{SP}_{\mathrm{t}}=\boldsymbol{\beta}_{\mathbf{0}}+\boldsymbol{\beta}_{1} \mathrm{CR}+$

$\boldsymbol{\mu} . .$.
Table 7: Regression Outcome for Big Manufacturing Firms

Dependent Varisbie, $\$$

Panel Leart Squares Tethique

Date: $09: 2219$ Time 115 ?

Sample: 20142018

Incbuded 10 cross-sections

Tocal otserations yo

\begin{tabular}{ccccc}
\hline Variable & Coefficient & SAd Errot & t-Statistic & Prob \\
\hline$C$ & 6.285210 & $0.63485 t$ & 9.900288 & 0.0000 \\
$C R$ & 0.456537 & 0.076540 & 5964671 & 0.0000 \\
\hline
\end{tabular}

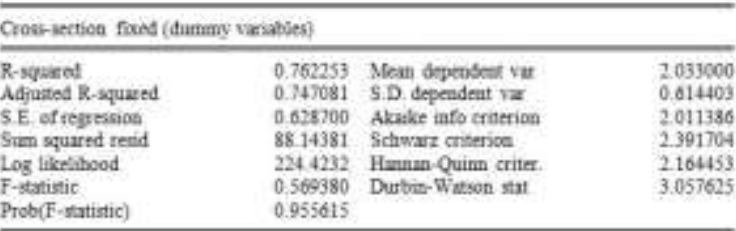

Source: Eview7, 2019

Analysis for Small Manufacturing Firms

Restatement of Objective Four

Assess how credit risk affects the share price of quoted small manufacturing firms in Nigeria.

$\mathrm{SP}_{\mathrm{t}}=\boldsymbol{\beta}_{\mathbf{0}}+\boldsymbol{\beta}_{1} \mathrm{CR}+$

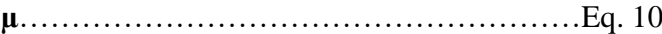

Table 8: Regression Outcome for Small Manufacturing Firms

Dependent Variskie Sp

Panel Lead Squares Tectrique

Dute 0925 is time: 08:13

Sample 20142018

tactuded 10 aross secoure

Toeal obcervaticas 5D

\begin{tabular}{|c|c|c|c|c|}
\hline Variatic & Coelficient & Std. Etrot & F-5tatiest & Prob. \\
\hline c & 4.147381 & 0.462396 & 8969916 & 0000 \\
\hline$C R$ & $=0.277381$ & 0.023277 & -11.91640 & 0.0000 \\
\hline
\end{tabular}

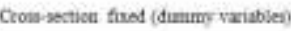

\begin{tabular}{|c|c|c|c|}
\hline R. squeed & 0.405951 & She desendear vat & 0.389000 \\
\hline Adjusend R-gruxed & 0.437183 & SD desentert tor & 0.193491 \\
\hline S.E. of tegression & 0.145159 & Akrike info criterion & -0.920062 \\
\hline Sten squard resid & $+\cos 369$ & Sthurze cribenon & -0.53994 \\
\hline Log lifcelthood & 142.0327 & Henme-Quna criter & 0.767195 \\
\hline E-stanstic & 8.499133 & Durtin Watton stat & $2.07108 s$ \\
\hline Prob(F-statintes & 0.006000 & & \\
\hline
\end{tabular}

Source: Eview7, 2019

\section{Discussion of Findings}

This study appraises the influence of dividend payment on share prices of the quoted manufacturing firms in Nigeria. In response to Table 1, dividend per share was revealed to positively influence share price of high geared manufacturing firms in Nigeria. This implies that, $1 \%$ rise in DPS will bring about a rise in SP. Similarly, Table 2 revealed that dividend per share positively influence share price of low geared manufacturing firms in Nigeria. This implies that, $1 \%$ 
rise in DPS will bring about a rise in SP. This result is line with the outcome of Mohannad et al (2018) although it did not indicate if the firms were highly geared or not.

Table 3 EPS was revealed to positively influence SP of dividend paying manufacturing firms in Nigeria. This signifies that for every $1 \%$ rise in EPS, there will be a similar increase in SP. This outcome corroborates with the result of the study conducted by Iqbal et al. (2015) inferring that, EPS determines significantly the share prices and the availability of future funds for dividend payment and reinvestment. Regarding the non-dividend paying manufacturing firms, it was revealed in Table 4 that, EPS positively influences SP. This signifies that for every $1 \%$ rise in EPS, there will be a similar increase in SP. This outcome is consistent with the study of Ishfaq (2018). It therefore implies that, EPS has the potential of raising future capital for reinvestment in non-dividend paying firms.

As regard to Table 5, DY was revealed a have an adverse effect on SP of old manufacturing firms in Nigeria. This implies that when DY increases by $1 \%$, the SP will decrease by $1 \%$. However, this outcome does not corroborate with the result of Freshia and Pauline (2016) where in this study, there is positive association of DY with SP. Considering new manufacturing firms, Table 6 established that, DY adversely influences SP. This implies that when DY increases by $1 \%$, the SP will decrease by $1 \%$. However, this outcome does not corroborate with the result of Freshia and Pauline (2016) where in this study, there is a positive association between DY and SP.

Table 7 reveals that, CR positively influences $\mathrm{SP}$ of big manufacturing firms in Nigeria. This implies that when CR increases by $1 \%$, the SP will increase by $1 \%$. Literature does not empirically emphasize the effect of credit risk on share prices of manufacturing firms in Nigeria. However, Table 8 revealed that CR negatively influences SP of small manufacturing firms in Nigeria. This implies that when CR increases by $1 \%$, the SP will decrease by $1 \%$.

The variables used in the study are dividend per share, earnings per share, dividend yield and credit risk. In as much as these variables used in the study are important, some are given optimum attention in investment decisions. In finance, dividend per share had been given optimum attention because of its cash flow nature. Only dividend announcement had caused great influence in share price in any capital market. Finance analysts over time have used dividend announcement in the form of insider information to manipulate the share price. The arguments of dividend relevance surpass the argument of dividend irrelevance. However, dividend argument had led to dividend theory. Most academic studies on dividend payment included dividend per share as relevant independent variable.

\section{Conclusion and Recommendations}

Based on the findings from the analysis, it can be observed that all the variables adopted in the model employed are significant. Hence, this led the researcher to draw a conclusion that, the findings achieved the research objectives. This study makes a significant contribution to the body of knowledge by empirically revealing the evidence on how dividend payment influences the price of share of manufacturing companies in Nigeria.

In view of the study's analysis, the coefficient of determination reveals more than average percent signifying that the dependent variable captured the level of significance of the independents variables. On this note, we can draw our conclusion that the manufacturing companies that are highly geared have a better model than the low geared companies, while dividends paying manufacturing companies have a better model compared to non-dividend paying manufacturing companies. Inclusively, the new and old manufacturing companies have a fair model implying that in totality, the manufacturing companies in Nigeria are not operating at the optimal level. Big and small manufacturing companies are progressing as the model of big manufacturing companies out-way the model of small manufacturing, as revealed by the coefficient of determination (R-square).

Parallel to the findings discovered in this work, it is therefore recommended that credit risk should be effectively and efficiently managed by small manufacturing companies in particular in order to eliminate its adverse influence on their share price. Also, the manufacturing companies that are not paying dividend with adequate earnings per share should be dividend in order to make the sector attractive to the investors. The government should provide the enabling environment for manufacturing companies to thrive and survive in Nigeria. Finally, well-reputable companies should be eager to pay out smooth dividends rather than investing more on the growth opportunities

\section{References}

Ahmed, B. I., Raja, N. J. Khan, N. S. (2017). Impact of Dividend Policy on Stock Prices of Firm. International Scientific Journal Theoretical and Applied Science, Vol. 3, No. 47, pp. 32-37.

Akram, B. (2017). Dividend Payment and its Impact on the Value of Firm Listed on Istanbul Stock Exchange, International Journal of Economics and Finance Issues, Vol. 7, Nol. 2, pp. 370376.

Alfred. C. O., Vincent, N. E. and Jessie, I. C. (2019). Effect of Dividend Policy on Stock Prices: Evidence from Nigeria. International Journal of Economics and Financial Management, Vol. 4 No. 3.

AlQudah, A., Yusuf, D. \& El-Deen, A.N. (2015). Stock Price Volatility and Dividend Policy in Jordanian Firms. Research Journal of Finance and Accounting, 6(22), 15-22. 
Augustine, N. O., Odum, C. G., Omeziri, R. I. and Chinedu, F. E. (2019). Impact of Dividend Payout Ratio on the Value of Firm: A Study of Companies Listed on the Nigerian Stock Exchange. Indonesian Journal of Contemporary Management Research, Vol. 1, No. 1, pp. 25-34.

Freshia, M. W. and Pauline, A. O. (2016). Cash Dividend Change Announcement Effect on Share Price Returns: Evidence From Nairobi Securities Exchange. The International Journal of Business and Finance Research, Vol. 10, No. 3, pp. 39-47.

Gordon, M. J. (1959). Dividends, Earnings and Stock Prices. Review of Economics and Statistics, Vol. 41, No. (2), pp. 99-105.

Gordon, M. J. (1963). Optimal Investment and Financing Policy. Journal of Finance, 18(2), pp. 264-272.

Iqbal, A., Ahmed, F., Zaidi, S.S.Z. and Raza, H. (2015). Determinants of share prices, evidence from Oil and Gas and Cement sector of Karachi Stock Exchange (A Panel Data Approach). Journal of Poverty, Investment and Development, 8(1), 14-19.

Ishfaq, A. (2018). Impact of Dividend Per Share and Earnings Per Share on Stock Prices: A Case Study from Pakistan (Textile Sector). International Journal of Social Sciences, Humanities and Education, Vol. 2, No. 2.

Jakata, O., and Nyamugure, P. (2015). The effects of dividend policy on share prices: Empirical evidence from the Zimbabwe Stock Exchange. International Journal of Science and Research, 4(10), 674-683.

Joseph, K. C. and Symon, K. K. (2017). Effect of Dividend Policy on Share Price Performance: A Case of Listed Insurance Companies at the Nairobi Securities Exchange, Kenya. International Journal of Accounting, Finance and Risk Management. Vol. 2, No. 3, pp. 98106.

Lintner, J. (1956). Distribution of Incomes of Corporations among Dividends, Retained Earnings, and Taxes, American Economic Review, 46 (2), pp. 97-113.

Miller, M. H., and Modigliani, F. (1961). "Dividend policy, growth and valuation of shares", Journal of Business.(34), 411-33.

Muhannad, A. A., Ashraf, M. S. A. and Hussein, M. A. (2018). The Effect of Dividend Policy On Stock Price Volatility: Empirical Evidence From Amman Stock Exchange. Academy of Accounting and Financial Studies Journal, Vol. 22, No. 2, pp. 1-8.
Sharma S. (2011). Determinants of equity share price in India. Journal of Arts, Science and Commerce. 2(4), 51-60. 